\title{
Relation between Expressed Emotion and Burden among Family Caregivers of Patients with Dementia
}

\author{
Mona Hassan Abdel Aal, Mervat Amin Sayed \\ Assistant Professor of Psychiatric / Mental Health Nursing, \\ Faculty of nursing, Ain Shams University \\ Lecturer of Community Health Nursing - Fayoum University
}

\begin{abstract}
Background: Expressed emotion EE has been a useful construct for understanding the relationship between family interactions and their ill relative The aim: of the present study was to assess relation between expressed emotion and burden among family caregivers of patients with dementia. The study subjects: consisted of 50 caregivers caring for patients with dementia. The study conducted at outpatient clinic of El Abbassia mental health hospital. Three tools: of data collection were used, the first: interviewing questionnaire to assess sociodemographic characteristics of family caregivers having patient with dementia, the second: Expressed emotion (EE) scale to asses expressed emotion among family caregivers having ill relative with dementia, the third: Burden scale to asses burden among caregivers having ill relative with dementia. . This study highlighted several important result: First, caregivers of patient with dementia having high Expressed emotion. Second, the result also revealed statistical significant relation between caregiver 's Expressed emotion and burden in caring patient with dementia. The study concluded: that high Expressed emotion as criticism, hostility, over involvement were high among caregivers than low Expressed emotion that include warmth, and positive remarks. Recommendation was, Expressed emotion management strategies for caregivers having patient with dementia .
\end{abstract}

Key Words: Expressed Emotion - Burden - Family Caregivers -Dementia 


\section{INTRODUCTION}

Dementia is a progressive and ultimately fatal collection of neurodegenerative diseases, which affect cognition and memory. Dementia can cause changes in memory, thought, navigation, language, behavior, mood and personality. Behavioral changes observed during the onset of dementia can include poor judgment, difficulty with problem solving, the inability to manage finances, misplacing items and disconnection from the date or season. (Richmond, 2014)\& (Gnonlonfoun et al 2014). In Egypt, community based surveys on dementia reported prevalence rates that ranged from $1.4 \%$ to $21.95 \%$. Dementia rates in Egypt increases markedly with the older ages. The mean age-adjusted prevalence estimate in Egypt is $4.5 \%$ as mentioned by Shata et al., 2015)

The most common form of dementia is Alzheimer's disease (AD), which corresponds to between $50 \%$ and $60 \%$ of all cases and represents one of the main causes of incapacity in adult life, followed by vascular dementia (VD), which represents between $15 \%$ and $20 \%$. The overburdening of caregivers who work with individuals suffering from dementia occurs as a result of a series of physical, psychological, emotional, social and financial problems, as such caregivers generally take responsibility for the care network required by the patient. However, caregivers are often not aware of how to adequately deal with the elderly, which can lead to a state of chronic stress, with occasional social isolation, thereby further increasing the risks of the caregiver suffering from physical and mental pathologies (Souza et al 2016)

Caring at home for a family member living with dementia is known to incur considerable demands. The daily challenges include supervision, managing the impact of the changes experienced by the person with dementia and coping with the changes that occur in relationships. The family members involved in care-giving experience high levels of stress, poor physical health and social isolation . Furthermore, evidence suggests that levels of stress and distress increase over time, as the changes arising from dementia progress and become wide ranging in their effect and impact upon the person living with dementia. (La Fontaine 2016)

Caregiving refers to attending to another individual's health needs. Caregiving often includes assistance with one or more activities of daily living (ADLs), such as bathing and dressing, as well as multiple instrumental activities of daily living (IADLs), such as paying bills, shopping and transportation. (Alzheimer's Association. 2016)

Caregiver burden has been defined as a multidimensional response to the negative appraisal and perceived stress resulting from taking care of an ill individual. Caregiver burden threatens the physical, psychological, emotional and functional health of caregivers. (Kim,et al 2011). Caregiver's burden have also been expressed through body pains, decrease in vitality and health in general restrictions in physical role and social categories (Boyer, Caqueo-Urízar, Richieri, Lancon, Gutiérrez-Maldonado, \& Auquier, 2012); (Caqueo- Urízar, Gutiérrez-Maldonado, \& Miranda-Castillo, 2009); (GutiérrezMaldonado, Caqueo-Urízar, Ferrer-García, \& Fernández-Dávila, 2012); (MollerLeimkuhler \& Wiesheu, 2012); (Osman, Alipah, Tutiiryani, \& Ainsah, 2010). (Caqueo 
et al 2014) and (Braine \& wray 2016). Family burden arise when the demands imposed by a patient's condition collide with caregiver's subjective ability to respond or when these demands obstruct the pursuit of other objectives of the care giver. ( Lindquist, 2016)

The construct of expressed emotion (EE) is now well established as an important measure of the family environment. Developed in the 1960s and 1970s in England by Brown, Birley, and Wing EE is most appropriately regarded as a measure of the patient-relative relationship. The concept of EE of EE has five dimensions or patterns which are criticism, hostility, emotional over - involvement, warmth and positive remarks. Only the first three were found to be related to high Expressed emotion. (Boyd, 2015), ( Hooley and Parker, 2006), (Pratibha, et al 2012) (ola, 2013 ) and (Ezzat et al, 2016)

Family Caregivers had different levels of expectations for the patient's functioning, with low expressed emotion (EE) caregivers allowing for low functioning due to an illness episode, while high EE caregivers were intolerant of any deficits or unmet expectations. Finally, low EE caregivers differed from high EE caregivers in their calm emotional reactions and flexibility when dealing with the patient's symptoms (Marudkar2007). ELMASRI,( 2011) Added to that, expressed emotion (EE) is the amount of intrusiveness, emotional response, negative attitude towards the illness, and tolerance/expectations conveyed by caregivers toward their patients. EE has been a useful construct for understanding the relationship between family interactions and their ill relative. (Yin $\mathbf{L i}$ 2013)

\section{Significance of the study:}

The assessment of expressed emotion involves analyzing both what is said and what manner in which it is said. Psychiatric mental health nurse has a role in providing the family caregivers with information about their relative's illness and treatment. Ensuring explanation of this information is essential to ensure understanding of it and to deal better with patient and avoiding blaming the patient about symptoms.

\section{AIM OF THE STUDY:}

The aim of the present study was to assess relation between expressed emotion and burden among family caregivers of patients with dementia. Research Question

What is the relation between family caregivers' expressed emotion and burden in caring patient with dementia?

\section{SUBJECTS AND METHOD:}

The present study was carried out through research design:

I- Technical design.

II- Operational design

III- Administrative design.

IV- Statistical design. 


\section{Technical Design:}

The technical design for this study includes research design, research setting, subjects of the study, and tools of data collection

\section{A- Research Design:}

Research design is a descriptive cross-sectional design.

\section{B- Research Setting:}

The study was conducted at outpatient clinic of El Abbassia mental health hospital. (Governmental hospital),

\section{C- Subjects:}

A convenient sample of fifty caregivers having ill relative with dementia, attending the outpatient clinic of El Abbassia mental health hospital, from total of about sixty patients recorded in one year flow in El Abbassia mental health hospital, .

\section{Inclusion criteria:}

Age: not less than twenty years

Sex: Both sexes

Relation to the patient: Son, Daughter, Wife, Sister, Son's wife

Dementia type: any type of dementia

\section{D- Tools of data collection:}

Data for this study were collected by using the following tools:

I- Interviewing questionnaire to assess Sociodemographic characteristics including age, marital status, relation to the patient, education, occupation, and income.

\section{II-Caregiver Expressed Emotion scale:}

The Level of Expressed Emotion (LEE) scale adapted from (Cole \& Kazarian, 1988) was used to assess family caregiver's Expressed emotion to ill relative with dementia. The questionnaire asses five domains,1- criticism, 2- hostility, 3- over involvement. These for high Expressed emotion. and also assessing low Expressed emotion, as 4- warmth and 5positive remarks.

\section{Scoring system:}

This questionnaire consists of 60 items and measures self-perceived EE based on five domains: (1) criticism includes statements 1, 55, 51,3,39,20,22,27. (2),hostility includes statements $8,24,25,58,54,45,6,42,36,44,10,19,35$. (3) over involvement includes statements $1,5,57,53,49,47,9,41,37,34,33,13,17,21,29$ (4) warmth includes statements $2,23,59,26,48,4,43,40,38,11,12,15,26$, and (5) positive remarks includes statements $56,60,52,46,32,14,16,31,18,30,28$. With true and false response options. Fourteen of the questions are phrased such that answering "True" is associated with reverse answers to some items of the five domains. Questions in those groups are phrased such that answering "yes" refers to high levels of EE. Each item is scored two points for a response true, that is high for EE one score for a response false, with higher scores indicating higher levels of expressed emotion. 


\section{III- Zarit Burden Interview}

Burden interview scale adapted from Zarit Burden Interview (ZBI; Zarit et al., 1980) It is a self-report scale to measure caregiver burden such as' physical, psychological, social and financial burden attributable to caregiving,

\section{Scoring system:}

The ZBI contains a 22-items checklist that requires participants to respond on a 3-points Likert-type scale, ranging from 1 (rare) to 2 (sometimes), and 3(always). The items for $21,20,1,14,10,8$ for physical burden. The items $19,18,16,3,11,9,7,5$ for psychological burden. The items 17,15.2,13,12,4,6,22 for social and financial burden.

\section{II- Operational Design:}

Consists of the preparatory phase, pilot study, validity and reliability, ethical considerations, field work.

\section{A- Preparatory phase:}

\section{Tool Reliability and Validity}

The instrument of Expressed emotion has been shown to be a valid and reliable (alpha=.84-.95). The instrument of burden has been demonstrated to have reliability and validity .Cronbach's alpha of .92 for assessing caregiver's burden of ill relative with dementia. To achieve the criteria of trust worthiness of the tool of data collection in this study, it was tested and evaluated by a jury group consisting of three experts in the nursing and medical field, such as Psychiatric/Mental Health Nursing and Psychiatric medicine to ascertain relevance, clarity, and completeness of the tools.

\section{Pilot Study:}

It was carried out with 5 caregivers having patient with dementia. It was done to ensure clarity, applicability, relevance, feasibility of conduction study tools, and time needed for each tool. Based on the findings of the pilot study, necessary modifications and clarifications of some questions were done to have more applicable tools for data collection.

\section{B- Ethical considerations:}

The aim of the study was explained to the caregivers to obtain their cooperation. Oral consent was obtained from the caregivers to ensure willingness to engage in the study, and the research maintains an anonymity and confidentiality of subject's data. Subjects were allowed to choose to participate or not, and they were informed that they have the right to withdraw from the study at any time without giving any reason.

\section{C- Field Work:}

Data collection for this study was carried out through about eight months in the period from beginning in January 2016 until beginning of September 2016. Data were collected through two days per week Sunday, \&Wednesday, those days of assigned for the elderly clinic at the outpatient clinic of El Abbassia mental health hospital. Taking one or two caregivers every day of attendance, the researcher explained to caregivers, the aim of the 
study which is family caregiver's Expressed emotion in response to burden of caring patient with dementia. The questionnaires were read, explained and choices were recorded, with the researcher's assistance, to clarify the statements. The time of answering questions took about 25 -35 minutes. After collecting the answered sheets from a caregiver, the researcher moved to another one to repeat the same previous steps, until completion of the process of data collection. Sometimes the researcher complete the tools of data collection by telephone interview after permission from the caregiver if he has no time to wait after taking the prescribed drugs from the outpatient clinic, and hurry to leave the outpatient.

\section{III- Administrative Design}

An official permission was obtained before conduction of the study, from the dean of faculty of nursing- Ain Shams University to the manager of El Abbassia mental health hospital.

\section{IV- Statistical Design}

The collected data were organized, categorized, tabulated and statistically analyzed using the Statistical Package for Social Science (SPSS) version 21 to the researcher explained to the caregivers, the aim of the study to assess expressed emotion as perceived by caregiver in response to burden of caring their ill relative with dementia. Data were presented in tables. The statistical analysis includes; percentage (\%), mean \pm Standard Deviation, $\left(\mathrm{X}^{2}\right)$, $P$ value, and alpha Chronbach test.

\section{Significance of results was described as follows:}

- Non significant (NS) difference obtained at p>0.05.

- Significant (S) difference obtained at $\mathrm{p}<0.05$.

- Highly significant (HS) difference obtained at $\mathrm{p}<0.001$.

\section{RESULTS:}

As illustrated in Table (1): that sociodemographic characteristics of family caregivers having patient with dementia were as the following, $84 \%$ of them, their age groups between 20 to less than 35 years old, $68 \%$ of them were married, daughters were represented as $30 \%$ of relationships to the patient, $52 \%$ of them were read and write, lastly their occupation and income were $64 \%$ work and $62 \%$ of them have no enough income.

Table (2): show physical burden among family caregivers having patient with dementia, it demonstrates that caregiver said that patient asks for more help than he/she needs represents sometimes $70 \%$, feeling that health has suffered because of involvement in patient care was $88 \%$. The total mean \pm SD was $13.16 \pm 1.54$

But psychological burden among family caregivers having patient with dementia revealed in table (3): that feeling uncertain about what to do about his relative was sometimes $60 \%$, feeling stressed between patient caring and trying to meet responsibilities for family or work represent sometimes $86 \%$, feeling strained when around your patient represent 
sometimes $82 \%$, and feeling angry when you are around your patient represent $76 \%$. The total mean $\pm \mathrm{SD}$ was $15.28 \pm 2.37$

In this respect, social and financial burden among family caregivers having patient with dementia in table (4): shows that feeling lost control of life since patient illness represent sometimes $88 \%$, feeling that they don't have enough money to take care of patient in addition to the rest of life expenses sometimes represents $66 \%$, feeling uncomfortable about having friends over because of patient caring represent sometimes $80 \%$. Feeling that patient affects relationships with other family members or friends in a negative way sometimes represents $74 \%$. The total mean \pm SD was $16.1 \pm 2.35$

About expressed emotion regarding criticism among family caregivers having patient with dementia appeared in table (5): clear that saying to patient lacks self control and blaming patient for things not going well represent $92 \%$ and $80 \%$ respectively. The total mean \pm SD was $12.62 \pm 1.37$

While expressed emotion regarding hostility among family caregivers having patient with dementia demonstrated in table (6): that making patient feel guilty for not meeting caregiver expectations was 58\%. Leaving patient feel overwhelmed represent $48 \%$. Getting angry with when things don't go right represent $84 \%$. The total mean \pm SD was $20.46 \pm 2.38$

It is obvious from table (7): expressed emotion regarding over involvement among family caregivers having patient with dementia that getting upset when patient doesn't check in with caregiver represent $82 \%$, always nosing into patient business represent $90 \%$. The total mean \pm SD was $25.44 \pm 1.61$

Table (8): shows expressed emotion regarding warmth among family caregivers having patient with dementia as making patient feel valuable as a person represent $90 \%$. Making patient feel relaxed when caregiver around was $98 \%$ and encourage patient to seek outside help when he/she is not feeling well represent $92 \%$. The total mean \pm SD was $22.34 \pm 1.65$

The fifth point of measuring expressed emotion is positive remarks among family caregivers having patient with dementia represented in table (9): that trying to make patient feel better when he/she is upset or ill represent $96 \%$. The total mean \pm SD was $18.26 \pm 1.21$

Table (10): demonstrates that total score for both expressed emotion and burden among family caregivers represent $94 \%$ and $90 \%$ respectively. The total mean \pm SD was $99.44 \pm$ 4.50 for expressed emotion and $44.54 \pm 5.01$ for burden

Relation between burden and expressed emotion in table (11) showed statistical significant relation between low burden and high expressed emotion represented by statistical significant difference obtained at $\mathbf{P}=0.003<0.05$. 
Table (1): Sociodemographic Characteristics of Family Caregivers Having Patient with Dementia

\begin{tabular}{|c|c|c|}
\hline Sociodemographic Characteristics & $\mathbf{N}$ & $\%$ \\
\hline \multicolumn{3}{|l|}{ Age } \\
\hline 20 less than 35 & 42 & 84 \\
\hline 35 to less than 50 & 8 & 18 \\
\hline $50+$ & - & - \\
\hline \multicolumn{3}{|l|}{ Marital status } \\
\hline Married & 34 & 68 \\
\hline Unmarried & 16 & 32 \\
\hline \multicolumn{3}{|l|}{ Relation to the patient } \\
\hline Son & 11 & 22 \\
\hline Daughter & 15 & 30 \\
\hline Wife & 13 & 26 \\
\hline Sister & 11 & 22 \\
\hline Son's wife & - & - \\
\hline \multicolumn{3}{|l|}{ Education } \\
\hline Read and write & 26 & 52 \\
\hline Pre University Study & 14 & 28 \\
\hline University Study & 10 & 20 \\
\hline Post Graduate Studied & - & - \\
\hline \multicolumn{3}{|l|}{ Occupation } \\
\hline work & 32 & 64 \\
\hline Does not work & 18 & 36 \\
\hline \multicolumn{3}{|l|}{ Income } \\
\hline Enough & 19 & 38 \\
\hline Not enough & 31 & 62 \\
\hline
\end{tabular}


Table (2): Physical Burden among Family Caregivers Having Patient with Dementia

\begin{tabular}{|c|c|c|c|c|c|c|}
\hline Physical Burden & Always & \% & Sometimes & \% & Rare & \% \\
\hline $\begin{array}{c}\text { 1-Do you feel you could do a } \\
\text { better job in caring for your } \\
\text { relative? }\end{array}$ & 21 & 42 & 26 & 52 & 3 & 6 \\
\hline $\begin{array}{c}\text { 2-Do you feel you should be } \\
\text { doing more for your relative? }\end{array}$ & 20 & 40 & 29 & 58 & 1 & 2 \\
\hline $\begin{array}{c}\text { 3- Do you feel that your relative } \\
\text { asks for more help than he/she } \\
\text { needs? }\end{array}$ & 13 & 26 & 35 & 70 & 2 & 4 \\
\hline $\begin{array}{c}\text { 4-Do you feel that your relative } \\
\text { seems to expect you to take care } \\
\text { of him/her as if you were the } \\
\text { only one he/she could depend } \\
\text { on? }\end{array}$ & 6 & 12 & 41 & 82 & 3 & 6 \\
\hline $\begin{array}{c}\text { 5-Do you feel your health has } \\
\text { suffered because of your } \\
\text { involvement with your relative? }\end{array}$ & 4 & 8 & 44 & 88 & 2 & 4 \\
\hline $\begin{array}{c}\text { 6-Do you feel your relative is } \\
\text { dependent on you? }\end{array}$ & 7 & 14 & 41 & 82 & 2 & 4 \\
\hline \begin{tabular}{c} 
Total Mean \pm SD \\
\hline
\end{tabular} & & & $13.16 \pm \mathbf{1 . 5 4}$ & & \\
\hline
\end{tabular}


Table (3): Psychological Burden among Family Caregivers Having Patient with Dementia

\begin{tabular}{|c|c|c|c|c|c|c|}
\hline Psychological Burden & Always & $\%$ & Sometimes & $\%$ & Rare & $\%$ \\
\hline $\begin{array}{l}\text { 1-Do you feel uncertain about what } \\
\text { to do about your relative? }\end{array}$ & 1 & 2 & 30 & 60 & 19 & 38 \\
\hline $\begin{array}{c}\text { 2-Do you wish you could leave the } \\
\text { care of your relative to someone } \\
\text { else? }\end{array}$ & 1 & 2 & 28 & 56 & 21 & $\sum Y$ \\
\hline $\begin{array}{c}\text { 3-Do you feel that you will be } \\
\text { unable to take care of your relative } \\
\text { much longer? }\end{array}$ & 1 & 2 & 45 & 90 & 4 & 8 \\
\hline $\begin{array}{l}\text { 4-Do you feel stressed between } \\
\text { caring for your relative and trying to } \\
\text { meet other responsibilities for your } \\
\text { family or work? }\end{array}$ & 5 & 10 & 43 & 86 & 2 & 4 \\
\hline $\begin{array}{c}\text { 5-Do you feel that you don't have as } \\
\text { much privacy as you would like } \\
\text { because of your relative? }\end{array}$ & 2 & 4 & 46 & 92 & 2 & 4 \\
\hline $\begin{array}{l}\text { 6-Do you feel strained when you are } \\
\text { around your relative? }\end{array}$ & 7 & 14 & 41 & 82 & 2 & 4 \\
\hline $\begin{array}{c}\text { 7-Are you afraid what the future } \\
\text { holds for your relative? }\end{array}$ & 5 & 10 & 43 & 86 & 2 & 4 \\
\hline $\begin{array}{c}\text { 8-Do you feel angry when you are } \\
\text { around your relative? }\end{array}$ & 3 & 6 & 38 & 76 & 9 & 18 \\
\hline Total Mean \pm SD & \multicolumn{6}{|c|}{$15.28 \pm 2.37$} \\
\hline
\end{tabular}


Table (4): Social and Financial Burden among Family Caregivers Having Patient with Dementia

\begin{tabular}{|c|c|c|c|c|c|c|}
\hline Social and Financial Burden & Always & $\%$ & $\begin{array}{c}\text { Someti } \\
\text { mes }\end{array}$ & $\%$ & Rare & $\%$ \\
\hline $\begin{array}{l}\text { 1-Do you feel you have lost } \\
\text { control of your life since your } \\
\text { relative's illness? }\end{array}$ & 1 & 2 & 44 & 88 & 5 & 10 \\
\hline $\begin{array}{l}\text { 2-Do you feel that you don't have } \\
\text { enough money to take care of } \\
\text { your relative in addition to the } \\
\text { rest of your expenses? }\end{array}$ & 14 & 28 & 33 & 66 & 3 & 6 \\
\hline $\begin{array}{l}\text { 3-Do you feel that because of the } \\
\text { time you spend with your relative } \\
\text { that you don't have enough time } \\
\text { for yourself? }\end{array}$ & 6 & 12 & 40 & 80 & 4 & 8 \\
\hline $\begin{array}{l}\text { 4-Do you feel uncomfortable } \\
\text { about having friends over because } \\
\text { of your relative? }\end{array}$ & 7 & 14 & 40 & 80 & 3 & 6 \\
\hline $\begin{array}{l}\text { 5-Do you feel that your social life } \\
\text { has suffered because you are } \\
\text { caring for your relative? }\end{array}$ & 8 & 16 & 40 & 80 & 2 & 4 \\
\hline $\begin{array}{c}\text { 6-Do you feel embarrassed over } \\
\text { your relative's behavior? }\end{array}$ & 11 & 22 & 36 & 72 & 3 & 6 \\
\hline $\begin{array}{l}\text { 7-Do you feel that your relative } \\
\text { currently affects our relationships } \\
\text { with other family members or } \\
\text { friends in a negative way? }\end{array}$ & 2 & 4 & 37 & 74 & 11 & 22 \\
\hline $\begin{array}{l}\text { 8-Overall, how burdened do you } \\
\text { feel in caring for your relative? }\end{array}$ & 6 & 12 & 25 & 50 & 19 & 38 \\
\hline Total Mean \pm SD & \multicolumn{6}{|c|}{$16.1 \pm 2.35$} \\
\hline
\end{tabular}


Table (5): Expressed Emotion Regarding Criticism among Family Caregivers Having Patient with Dementia

\begin{tabular}{|c|c|c|c|c|}
\hline $\begin{array}{c}\text { Expressed Emotion Regarding Criticism among } \\
\text { Family Caregivers }\end{array}$ & Yes & $\mathbf{\%}$ & No & $\%$ \\
\hline $\begin{array}{c}\text { 1-I say he/she just wants attention when he/she says } \\
\text { he/she is not well. }\end{array}$ & 40 & 80 & 10 & 20 \\
\hline $\begin{array}{c}\text { 2-I often accuse him/her of making things up when } \\
\text { he/she is not feeling well. }\end{array}$ & 29 & 58 & 21 & 42 \\
\hline $\begin{array}{c}\text { 3-I don't blame him/her when he/she is feeling } \\
\text { unwell. }\end{array}$ & 37 & 74 & 13 & 26 \\
\hline $\begin{array}{c}\text { 4-I say he/she lacks self-control. } \\
\text { he/she is unwell. }\end{array}$ & 46 & 92 & 4 & 8 \\
\hline $\begin{array}{c}\text { 5-I accuse him/her of exaggerating when he/she says } \\
\text { expectations. }\end{array}$ & 17 & 34 & 33 & 66 \\
\hline $\begin{array}{c}\text { 7-I blame him/her for things not going well. } \\
\text { 8-I say he/she causes his/her troubles to occur in } \\
\text { order to get back at me. }\end{array}$ & 17 & 34 & 33 & 66 \\
\hline Total Mean \pm SD & 10 & 20 & 40 & 80 \\
\hline
\end{tabular}


Table (6): Expressed Emotion Regarding Hostility among Family Caregivers Having Patient with Dementia

\begin{tabular}{|c|c|c|c|c|}
\hline $\begin{array}{c}\text { Expressed Emotion Regarding Hostility among } \\
\text { Family Caregivers }\end{array}$ & Yes & \% & No & \% \\
\hline $\begin{array}{c}\text { 1-I make him/her feel guilty for not meeting my } \\
\text { expectations. }\end{array}$ & 29 & 58 & 21 & 42 \\
\hline 2-I can't stand it when he/she is upset. & 19 & 38 & 31 & 62 \\
\hline 3-I leave him/her feeling overwhelmed. & 24 & 48 & 26 & 52 \\
\hline 4-I get irritated when things don't go right. & 40 & 80 & 10 & 20 \\
\hline 5-I make matters worse when things aren't going \\
well. & 28 & 56 & 22 & 44 \\
\hline 6-I butt into his/her private matters. & 39 & 78 & 11 & 22 \\
\hline 7-I don't make him/her nervous. & 24 & 48 & 26 & 52 \\
\hline 8-I get angry with him/her for no reason. & 13 & 26 & 37 & 74 \\
\hline 9-I get angry with him/her when things don't go \\
right. & 42 & 84 & 8 & 18 \\
\hline 10-I support him/her when he/she needs it. & 47 & 94 & 3 & 6 \\
\hline 11-I lose control of my temper. & 29 & 58 & 21 & 42 \\
\hline 12-I don't help him/her when he/she is upset or & 39 & 78 & 11 & 22 \\
feeling unwell. & & & & \\
\hline 13-I say it is not OK to seek professional help. & 42 & 84 & 8 & 16 \\
\hline Total Mean \pm SD & $\mathbf{2 0 . 4 6} \pm \mathbf{2 . 3 8}$ & \\
\hline
\end{tabular}


Table (7): Expressed Emotion Regarding Over Involvement among Family Caregivers Having Patient with Dementia

\begin{tabular}{|c|c|c|c|c|}
\hline $\begin{array}{c}\text { Expressed Emotion Regarding over Involvement } \\
\text { among Family Caregivers }\end{array}$ & Yes & $\mathbf{\%}$ & No & \% \\
\hline $\begin{array}{c}\text { 1-I say I understand if sometimes he/she doesn't want } \\
\text { to talk. }\end{array}$ & 45 & 90 & 5 & 10 \\
\hline $\begin{array}{c}\text { 2-I don't butt into his/her conversations. } \\
\text { 3-I get upset when he/she doesn't check in with me. }\end{array}$ & 41 & 82 & 9 & 18 \\
\hline 4-I don't ask a lot of personal questions. & 33 & 66 & 17 & 34 \\
\hline 5-I don't pry into his/her life. & 41 & 82 & 9 & 18 \\
\hline $\begin{array}{c}\text { 6-I am willing to gain more information to understand } \\
\text { his/her condition, when he/she is not feeling well. }\end{array}$ & 48 & 96 & 2 & 4 \\
\hline 7-I am not overprotective with him/her. & 35 & 70 & 15 & 30 \\
\hline 8-I insist on knowing where he/she is going. & 47 & 94 & 3 & 6 \\
\hline 9-I always have to know everything about him/her. & 49 & 98 & 1 & 2 \\
\hline 10-I hear him/her out. & 29 & 58 & 21 & 42 \\
\hline 11-I am always nosing into his/her business. & 45 & 90 & 5 & 10 \\
\hline 12-I am always interfering. & 42 & 84 & 8 & 16 \\
\hline 13-I don't insist on doing things with him/her. & 34 & 68 & 16 & 32 \\
\hline 14-I don't insist on being with him/her all the time. & 24 & 48 & 26 & 52 \\
\hline 15-I often check up on him/her to see what he/she is & 43 & 86 & 7 & 14 \\
\hline doing. & & & & \\
\hline Total Mean \pm SD & & $\mathbf{2 5 . 4 4} \pm \mathbf{1 . 6 1}$ & \\
\hline
\end{tabular}


Table (8): Expressed Emotion Regarding Warmth among Family Caregivers Having Patient with Dementia

\begin{tabular}{|c|c|c|c|c|}
\hline $\begin{array}{c}\text { Expressed Emotion Regarding Warmth among } \\
\text { Family Caregivers }\end{array}$ & Yes & $\mathbf{\%}$ & No & $\%$ \\
\hline 1-I calm him/her down when he/she is upset. & 12 & 24 & 38 & 76 \\
\hline 2-I make him/her feel valuable as a person. & 45 & 90 & 5 & 10 \\
\hline $\begin{array}{c}\text { 3-I try to reassure him/her when he/she is not feeling } \\
\text { well. }\end{array}$ & 20 & 40 & 30 & 60 \\
\hline 4-I am patient with him/her when he/she is not well. & 42 & 84 & 8 & 16 \\
\hline 5-I am understanding if he/she makes a mistake. & 46 & 92 & 4 & 8 \\
\hline $\begin{array}{c}\text { 6-I am tolerant with him/her even when he/she } \\
\text { doesn't meet my expectations. }\end{array}$ & 47 & 94 & 3 & 6 \\
\hline 7-When he/she is upset, I am a considerate person. & 46 & 92 & 4 & 8 \\
\hline $\begin{array}{c}\text { 8-I will take it easy with him/her, even if things aren't } \\
\text { going right. }\end{array}$ & 43 & 86 & 7 & 14 \\
\hline 9-I make him/her feel relaxed when I am around. & 49 & 98 & 1 & 2 \\
\hline $\begin{array}{c}\text { 10-I am sympathetic towards him/her when he/she is } \\
\text { not feeling well. }\end{array}$ & 48 & 96 & 2 & 4 \\
\hline $\begin{array}{c}\text { 11-I can see his/her point of view. } \\
\text { Thetshe is not feeling well. }\end{array}$ & 47 & 94 & 3 & 6 \\
\hline $\begin{array}{c}\text { 12-I encourage him/her to seek outside help when } \\
\text { he/she }\end{array}$ & 46 & 92 & 4 & 8 \\
\hline $\begin{array}{c}\text { 13-I don't know how to handle his/her feelings when } \\
\text { he/she is not feeling well. }\end{array}$ & 42 & 84 & 8 & 16 \\
\hline \begin{tabular}{c} 
Total Mean \pm SD \\
\hline
\end{tabular} & & & \\
\hline
\end{tabular}

Table (9): Expressed Emotion Regarding Positive Remarks among Family Caregivers Having Patient with Dementia

\begin{tabular}{|c|c|c|c|c|}
\hline $\begin{array}{c}\text { Expressed Emotion Regarding Positive } \\
\text { Remarks among Family caregivers }\end{array}$ & Yes & $\mathbf{\%}$ & No & \% \\
\hline $\begin{array}{c}\text { 1-I "fly off the handle" when he/she doesn't do } \\
\text { something well. }\end{array}$ & 36 & 72 & 14 & 28 \\
\hline $\begin{array}{c}\text { 2-I expect the same level of effort from him/her, } \\
\text { even if he/she doesn't feel well. }\end{array}$ & 38 & 76 & 12 & 24 \\
\hline 3-I expect too much from him/her. & 47 & 94 & 3 & 6 \\
\hline 4-I can cope well with stress. & 42 & 84 & 8 & 16 \\
\hline $\begin{array}{c}\text { 5-I am realistic about what he/she can and cannot } \\
\text { do. }\end{array}$ & 45 & 90 & 5 & 10 \\
\hline 6-I don't panic when things start going wrong. & 31 & 62 & 19 & 38 \\
\hline 7-I don't feel that he/she is causing me a lot of \\
trouble. & 35 & 70 & 15 & 30 \\
\hline $\begin{array}{c}\text { 8-I try to make him/her feel better when he/she is } \\
\text { upset or ill. }\end{array}$ & 48 & 96 & 2 & 4 \\
\hline 9-I can't think straight when things go wrong. & 44 & 88 & 6 & 12 \\
\hline 10-I am able to be in control in stressful situations. & 42 & 84 & 8 & 16 \\
\hline 11-I understand his/her limitations. & 47 & 94 & 3 & 6 \\
\hline
\end{tabular}




\section{Total Mean \pm SD}

$18.26 \pm 1.21$

Table (10): Total Score of Expressed Emotion and Burden among Family Caregivers having Patient with Dementia

\begin{tabular}{|c|c|c|}
\hline $\begin{array}{c}\text { Total Score of Expressed Emotion } \\
\text { and Burden among Family } \\
\text { Caregivers }\end{array}$ & $\mathbf{N}$ & $\%$ \\
\hline $\begin{array}{c}\text { Expressed emotion } \\
\text { High } \\
\text { Low } \\
\text { Mean and Standard Deviation }\end{array}$ & $\begin{array}{c}47 \\
3\end{array}$ & $\begin{array}{c}94 \\
6 \\
\mathbf{9 9 . 4 4} \pm \mathbf{4 . 5 0}\end{array}$ \\
\hline $\begin{array}{c}\text { Burden among caregiver } \\
\text { High } \\
\text { Moderate } \\
\text { Low } \\
\text { Mean and Standard Deviation }\end{array}$ & $\begin{array}{c}3 \\
45 \\
2\end{array}$ & $\begin{array}{c}6 \\
90 \\
4 \\
\mathbf{4 4 . 5 4} \pm \mathbf{5 . 0 1}\end{array}$ \\
\hline
\end{tabular}

Table (11): Relation between Burden and Expressed Emotion among Family Caregivers Having Patient with Dementia

\begin{tabular}{|c|c|c|c|c|}
\hline \multirow{2}{*}{ Burden } & \multicolumn{2}{|c|}{ Expressed emotion } & \multirow{2}{*}{ Chi } & \multirow{2}{*}{ P value } \\
\cline { 2 - 3 } & High & Low & & \\
\hline High & 2 & 1 & 11.978 & 0.003 \\
Moderate & 1 & 1 & & \\
Low & 44 & 1 & & \\
\hline
\end{tabular}

\section{DISCUSSION:}

Humans are relational beings, and their existence is linked to the expression of their experiences in the world, embracing the totality of this experience that is presented in the expression, me-the other-the world. The individual can change and act on the environment he lives in according to his experiences. (Ribeiro, et al 2016). The aim of the present study was to assess relation between expressed emotion and burden among family caregivers of patients with dementia.

Concerning physical burden among family caregivers, the majority of the sample feeling that health has suffered because of involvement in patient care. while psychological burden among family caregivers, founded as, less than two thirds sometimes feeling uncertain about what to do about their relative and the majority sometimes suffered about feeling stressed between patient caring and trying to meet responsibilities for family or work, and feeling strained when around their patient. Added to that most of the sample feeling angry when around their patient. From the researcher point of view, these may be 
attributed to much time allocating for caring, and accumulation of duties and responsibilities of caregiver and cannot be achieved and lead to strain and stress.

This is consistent with El-Masri, ( 2011). Who said that People with mental illness who live with their families, and they often depend on a family member's assistance and involvement in providing care for them at home. These family members are often inadequately prepared to be the main caregiver for the ill relative. Therefore, a severe burden imposed upon the whole family when caring for a member with mental illness because of un-predictable and bizarre behavior, external stressors. In this respect, Yin Li, (2013), \& Souza, et al., (2016), approved that many caregivers of people with dementia experience negative health outcomes associated with stress as a result of care giving. In fact, informal caregivers have been called the "second victims" or "hidden patients" of the disease with risks for social isolation and stress. And the overburdening of caregivers who work with individuals suffering from dementia occurs as a result of a series of physical, psychological, emotional, social and financial problems.

Regarding social and financial burden, the family caregivers meet, it is clear that the majority sometimes feeling lost control of life since patient illness, about two thirds sometimes feeling that they don't have enough money to take care of patient in addition to the rest of life expenses sometimes, more than two thirds feeling that patient affects relationships with other family members or friends in a negative way. It is appeared that total mean scores were high for social and financial burden, then psychological burden, then physical burden was the least, that may be due to cost of patient's treatment and caregiver's responsibilities. This result was supported by Kim,et al (2011), who confirmed that caregivers of individuals with dementia experience moderate or severe levels of burden. This was not unexpected, as providing more hours of care giving, feel more responsible for care giving tasks as part of their familial duties and experience the greater physical and emotional closeness of the care-recipients.

On the other hand, expressed emotion, which is the term, refers to an index of several particular emotions, attitudes, and behaviors expressed by family caregivers toward people with mental disorders. Regarding criticism as in blaming patient for things not going well representing most of the sample. The total mean score was higher than total mean score in Marudkar, (2007). Expressed emotion regarding over involvement among family caregivers was more than three quarters, of the sample getting upset when patient doesn't check in with caregiver, most of the sample always nosing into patient business. It is appeared that total mean scores were high for over involvement, then hostility, and the least score for criticism. From the researcher point of view, this is for high Expressed emotion, which is due to our culture of knowing everything about our ill relative concerns. Research has shown that the factor of EE most associated with care-recipients health outcomes can change from one culture to another (López et al., 2009).

For example, most of earlier studies of EE in western countries listed criticism as the predominant factor of EE, while emotional over-involvement is the choice for Mexican- 
American family caregivers (Breitborde et al., 2009; López et al., 2009). And a study result by Yin $\mathbf{L i}$, (2013) showed the EE intrusiveness subscale to have the highest mean rate of scores. The EE intrusiveness subscale and emotional response to illness subscale have been linked to the concept of EOI while the other two subscales with lower means (expectations/tolerance and negative attitude towards the illness) can be related to the original concepts of criticism and hostility.

On the other hand, expressed emotion regarding warmth among family caregivers most of the sample making patient feel valuable as a person and making patient feel relaxed when caregiver around and encourage patient to seek outside help when he/she is not feeling well. But positive remarks which is the fifth point of measuring Expressed emotion among family caregivers, most of the sample trying to make patient feel better when he/she is upset or ill. This is related to character of Egyptian people which are sympathetic, kind, and adherence to religion's moral and traditions.

It is appeared that total mean scores for warmth was greater than positive remarks, concerning low Expressed emotion, that could be due to emotional bonds among Egyptian families,and the concept of familism is deeply rooted in the Egyptian mind, taking care of a family member with illness regardless of their dissatisfaction. Which agree with Abyad (2015), who said that middle-eastern culture ensures respect for the elderly and values highly the natural bonds of affection between all members of the family. The eldest members are a source of spiritual blessing, religious faith, wisdom and love.

The relation between burden and Expressed emotion showed statistical significant relation between burden and high expressed emotion, the result in agreement with Yin $\mathbf{L i}$ (2013)., who documented that high EE caregivers of patients with dementia are more likely to have higher levels of burden. Which also in line with Pratibha, et al (2012) who revealed that high EE relatives had considerably higher mean scores for burden of care. The study shows that EE and the burden of care are related, EE and burden both measure aspects of the relationship between relatives and patients. Thus findings suggest that EE and burden of care are more dependent on relative's appraisal of the patient condition than on patient's actual deficits.

\section{CONCLUSION:}

The majority of family caregivers having physical, psychological and social and financial burden, The total mean score was high for social and financial burden, then psychological burden, and the least for physical burden. Regarding high expressed emotion, the total mean scores were high for over involvement, then hostility, and the least score for criticism. While low expressed emotion, the total mean score for warmth was greater than positive remarks. Added to that, there was statistical significant relation between burden and high expressed emotion among family caregivers having patient with dementia.

\section{RECOMMENDATIONS:}

- Awareness program for family caregivers of patient with dementia about meaning of expressed emotion and its effect on patient's condition as improvement or deterioration. 
- Training program about expressed emotion management strategies for caregivers having patient with dementia.

-Education program about expressed emotion in nursing curriculum.

- Psycho- educational programs and counseling services for family caregivers of patients with dementia in order to help them how to cope with the burden of caring patient with dementia.

\section{Further Researches}

- Researches about expressed emotion and its effect on work achievement.

- Researches about expressed emotion in relation between family attachment and children psychological health.

- Researches about expressed emotion and its effect on patient suffering from chronic illness like cancer.

\section{REFERENCES:}

Abyad A (2015): Alzheimer's in the Middle East. JSM Alzheimer's Dis Related Dementia 2(1): 1012.

Alzheimer's Association. 2016: Alzheimer's Disease Facts and Figures. Alzheimer's \& Dementia 2016;12(4).

Boyd, M. (2015): Psychiatric Nursing Contemporary Practice, $5^{\text {th }}$ ed, Wolters Kluwer, PP; 289.

\section{Boyer, L., Caqueo-Urízar, A., Richieri, R., Lancon, C., Gutiérrez-}

Maldonado, J., \& Auquier, P. (2012): Quality of life among caregivers of patients with schizophrenia: A cross-cultural comparison of Chilean and French families. BMC Family Practice, 13, 42.

Braine, M. \& Wray, J.( 2016): Supporting Families and Carers: A Nursing Perspective, CRC Press, PP105.

Breitborde, N. J. K., López, S. R., Chang, C., Kopelowicz, A., \& Zarate, R. (2009). Emotional over-involvement can be deleterious for caregivers' health: Mexican Americans caring for a relative with schizophrenia. Social Psychiatry and Psychiatric Epidemiology, 44(9), 716-723.

Caqueo, A. Miranda, C. Lemos, S. lyn Lee, S. Ramírez, M. and Mascayano,F (2014): An updated review on burden on caregivers of schizophrenia patients. Psicothema 2014, Vol. 26, No. 2, 235-243.

Caqueo-Urizar, A., Gutiérrez-Maldonado, J., \& Miranda-Castillo, C.(2009): Quality of life in caregivers of patients with schizophrenia: A literature review. Health and Quality of Life Outcomes, 7, 84. 
Cole, J. D., \& Kazarian, S. S. (1988): The level of expressed emotion scale: A new measure of expressed emotion. Journal of Clinical Psychology, 44(3), 392-397.

EL-MASRI,Y . (2011): Caregivers' Expressed Emotion in Response to Patient Psychiatric Symptoms. Med. J. Cairo Univ., Vol. 79, No. 2, March: 49-57, www.medicaljournalofcairouniversity.com.

Gnonlonfoun, D.D., Adjien, C., Ossou-Nguiet, P.M., Diallo, L.L., Houannou, O., Acakpo, J., Goudjinou, G., Houinato, D. and Avode, D.G. (2014): Prevalence of Dementia and Its Associated Factors in Cotonou Teaching Hospital, Benin. Advances in Alzheimer's Disease, 3, 94-106. http://dx.doi.org/10.4236/aad.2014.32010.

Gutiérrez-Maldonado, J., Caqueo-Urízar, A., Ferrer-García, M., \&Fernández-Davila, $P$. (2012): [Infl uence of perceived social support and functioning on the quality of life of patients with schizophrenia and their caregivers]. Psicothema, 24(2), 255-262.

Hooley, J. and Parker, H.( 2006): Measuring Expressed Emotion: An Evaluation of the Shortcuts. Journal of Family Psychology, Vol. 20, No. 3, 386-396.

KIM H. , CHANG M. , ROSE K. \& KIM S. (2011): Predictors of caregiver burden in caregivers of individuals with dementia. Journal of Advanced Nursing 68(4), 846-855. doi: $10.1111 / \mathrm{j} .1365-2648.2011 .05787$.

La Fontaine, J., Jutlla, K., Read, K., Brooker, D., and Evans, S (2016):The Experiences, needs and Outcomes for Carers of People with Dementia. Literature Review. University of Worcester Association for Dementia Studies.

Lindquist, L( 2016): New Directions in Geriatric Medicine: Concepts, Trends, and Evidence- Based; $1^{\text {st }}$ ed; UKA; PP117.

López, S. R., Garcia, J. R., Ullman, J. B., Kopelowicz, A., Jenkins, J., Breitborde, N. J., \& Placencia, P. (2009). Cultural variability in the manifestation of expressed emotion. Family Process, 48(2), 179-194.

Marudkar, M., (2007): Influence of the Carer's Expressed Emotion on the Course and Twelve-month Outcome of Patients with Alzheimer's disease. Doctorate Thesis of Philosophy at the University of Leicester Division of Psychiatry for the Elderly Department of Health Sciences University of Leicester.

Mohammed,H. Mourad,Gh. Elganzoury, G.(2016): Expressed emotion among Families Having Schizophrenic Patient. Master thesis, Faculty of Nursing, Ain Shams University.PP:92.

Moller-Leimkuhler, A.M., \& Wiesheu, A. (2012). Caregiver burden in chronic mental illness: The role of patient and caregiver characteristics. European Archives of Psychiatry and Clinical, 262(2), 157-166. 
Ola,B (2013): The Influence of Burden of Care and Perceived Stigma on Expressed emotion of Relatives of Stable Persons with Schizophrenia in Nigerian SemiUrban/Urban Settings, Master's Dissertation in international Mental Health; Universidade Nova de Lisboa.

Osman, C.B., Alipah, B., Tutiiryani, M.D., \& Ainsah, O. (2010): Depressive disorders and family functioning among the caregivers of patients with schizophrenia. East Asian Archives of Psychiatry, 20(3), 101-108.

Pratibha, SPK Jena, MS Bhatia(2012): Expressed Emotion Research in Severe Mental Illness., Delhi Psychiatry Journal Vol. 15 No.1.

Ribeiro, B.S.S., Rezende, L.K., Sa, S.P.C. and Machado, W.C.A. (2016): The Impact of Alzheimer's Disease on the Life of Family Caregivers: A Phenomenological View. Open Journal of Nursing, 6, 333-341. http://dx.doi.org/10.4236/ojn.2016.64035.

Richmond,( 2014): Dementia Care Best Practices In The Common Wealth., Report to Delegate Orrock, Chair House Committee on Health, Welfare and Institutions Virginia Department for Aging and Rehabilitative Services Commonwealth.

Shata ZN1*, El-Kady HM2, Ibrahim HK3 (2015): Reliability and Validity of an Arabic Version of Quality of life - Alzheimer Disease in Alexandria, Egypt., . Int J Behav Res Psychol, 3(8), 157-163.

Souza,C. Gustavo, A. Cristina, S. and Assis, F (2016): Factors associated with the resilience of family caregivers of persons with dementia: a systematic review, Rev. Bras. Geriatr. Gerontol., Rio de Janeiro, 19(4):703-714.

Yin Li, Ch., (2013): Expressed Emotion, Depression, Burden, and Perceived Health in Family Caregivers of Older Adults with Dementia in Taiwan. A dissertation submitted in partial fulfillment of the requirements for the degree of Doctor of Philosophy University of Washington.

Zarit, S. H., Reever, K. E., \& Back-Peterson, J. (1980): Relatives of the impaired elderly: Correlates of feelings of burden. Gerontologist, 20(6), 649-655. 


\title{
العلاقة بين التعبير الإنفعالي والأعباء التي تواجه أفراد الأسر القائمين علي رعاية مرضي
}

\section{الخرف}

\author{
منى حسن عبد العال ، ميرفت أمين سعيد
}

أستاذ مساعد التمريض النفسى والصحة العقلبة كلبة التمريض جامعة عبن شمس ، مدرس تمريض صدة الآسرة

والمجتمع جامعة الفبوم

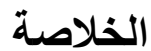

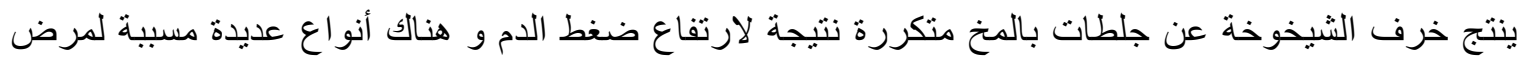

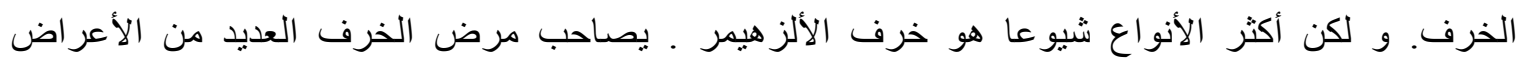

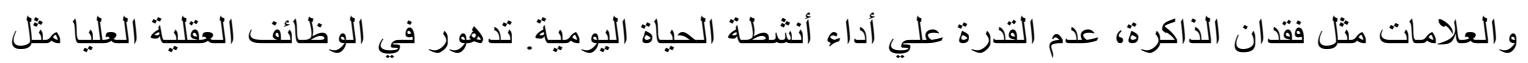

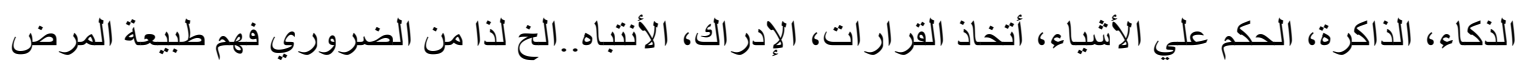
لأفر اد الأسر القائمين علي رعاية مريض الخرف و الطريقة المثلي في الرعاية لتخفيف عبء الرعاية علي القائم الرداه

تثير التعبير ات الانفعالية إلي توجيه العو اطف المعينة والمواقف و السلوكيات التي يعبر عنها الأقارب نحو أحد أفر اد الأسرة في أزمات الحياة المختلفة، التي قد يصاب بها أحد أفر اد الأسرة. وهذه التعبير ات ليست على قدر من لون التعبير العاطفي و إنما هي مقياس لمدى محادثات أفر اد الأسرة عن فرد آخر من العائلة في محنته المرضية. و المواقف الثناثة المتعلقة بالتعبيرات الانفعالية هي: اــ المعاداة: وتثبر الى الرفض الواضح و الصريح لهذا

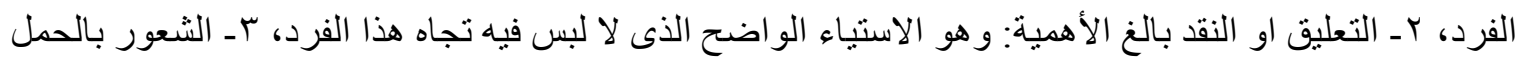

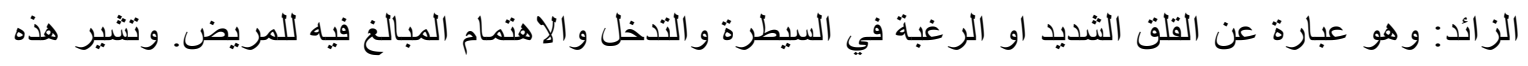
النقاط الثلاث الي التعبير الانفعالي المرتفع. أما التعبير الانفعالي المنخفض فهو الاسلوب الرحيم في التعامل مع المريض من قبل أفر اد الأسرة خاصة فرد العائلة المسئول، المنوط برعاية المريض، والذي عليه العبئ الأكبر

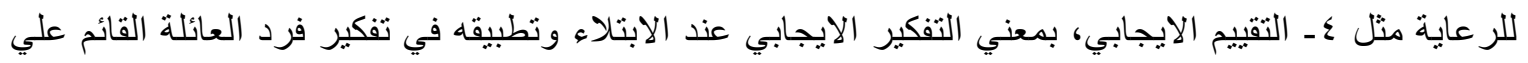

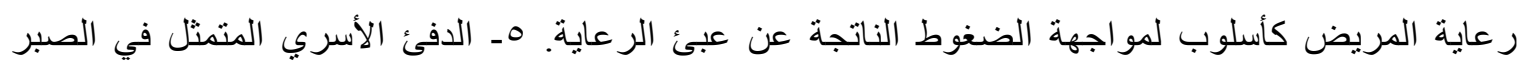

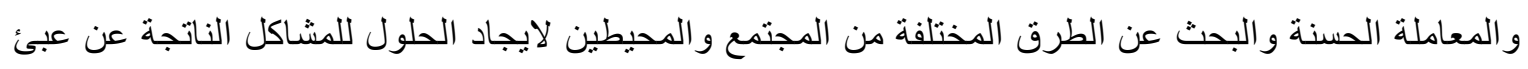
الر عاية، الي جانب الهدوء في مو اجهة المشكلة الخاصة بأحد أفر اد الأسرة، و الابتسامة المستمرة مع تقديم الر عاية و الكلام الطيب المصاحب لنقديم الرعاية. 